\title{
Karakter Wirausaha pada Industri Mikro Pangan Olahan di DIY dan Faktor-Faktor yang Mempengaruhi
}

\author{
D $01: 10.18196 /$ agr.2123
}

\begin{abstract}
ABSRACT
Study about entrepreneurial character of micro business processed foods maker in the province of Yogyakarta covering 5 districts was conducted. The sample used on this study was they who are have many firm in each district. The study aims to determine the character of the entrepreneurs and analyzed its relationship with business performance, especially in terms of the efficiency of their business. Descriptive analysis was used to find out entrepreneurial character based on data assessed with Liekert's scales and use path analysis to determine the relationship between entrepreneurial character with efficiency in its business performance. The results of the analysis showed that the entrepreneurial character of the businessmen in general was less
\end{abstract}

strong. External environmental factors were conducive, although the social environment factors were less supportive. Family support was the only one that high. Leadership has a strong influence on future orientation, character of ownership of the business, responsivity and creativity to facing change. Character of leadership was in a strong level so that, if improved, it will enhance the character of entrepreneurial capacity. Characters of future orientation also exist at the strong level.

Key words: entrepreneurial character, factor influencing, the micro firm of food made.

\section{INTISARI}

Penelitian karakter wirausaha pelaku usaha mikro pangan olahan dilakukan di lima (5) kabupaten yang ada di Provinsi DIY. Sampel industri mikro pangan olahan ditentukan yang unit usahanya terbanyak di setiap kabupaten. Penelitian bertujuan untuk mengetahui karakter wirausaha dari pelaku usaha mikro pangan olahan dan dianalisis hubungannya dengan kinerja usahanya, khususnya terkait efisiensi usaha. Karakter wirausaha dianalisis secara deskriptif berdasarkan data yang dinilai dengan skala Likert, sedangkan hubungan antara karakter wirausaha dengan efisiensi usaha dianalisis dengan analisis jalur (path analysis). Hasil analisis menyatakan bahwa karakter wirausaha yang dimiliki pelaku usaha secara umum kurang kuat. Faktor lingkungan eksternal termasuk kondusif, dengan dukungan keluarga yang tinggi; walau untuk faktor lingkungan sosial kurang mendukung. Karakter jiwa kepemimpinan memiliki pengaruh kuat terhadap karakter orientasi ke depan, karakter kepemilikan jaringan usaha, dan karakter tanggap dan kreatif menghadapi perubahan. Karakter jiwa kepemimpinan ada pada level cukup kuat, sehingga apabila ditingkatkan akan meningkatkan juga kapasitas karakter wirausaha yang dipengaruhinya. Demikian juga untuk karakter orientasi ke depan yang juga ada pada level cukup kuat.

Kata kunci: karakter wirausaha, faktor yang mempengaruhi, industri mikro pangan olahan. 


\section{PENDAHULUAN}

Usaha mikro kecil dan menengah (UMKM) mempunyai peranan yang penting dalam pertumbuhan ekonomi suatu negara. Hampir 90 persen dari total cabang usaha yang ada di dunia merupakan UMKM. Selain itu, UMKM mempunyai peranan penting dalam hal penyerapan tenaga kerja; studi empiris menunjukkan bahwa UMKM pada skala internasional merupakan sumber penyediaan lapangan pekerjaan. Peranan UMKM dalam penyerapan tenaga kerja, baik di negara maju maupun negara berkembang, termasuk Indonesia, bisa dikatakan mempunyai peranan yang penting dalam penanggulangan masalah pengangguran.

Beberapa keunggulan UMKM dibandingkan dengan usaha besar antara lain: i) inovasi dalam teknologi yang telah dengan mudah terjadi dalam pengembangan produk; ii) hubungan kemanusiaan yang akrab di dalam perusahaan kecil; iii) kemampuan menciptakan kesempatan kerja cukup banyak atau penyerapannya terhadap tenaga kerja; iv) fleksibilitas dan kemampuan menyesuaikan diri terhadap kondisi pasar yang berubah dengan cepat dibanding dengan perusahaan skala besar yang pada umumnya birokratis; v) terdapatnya dinamisme manajerial dan peranan kewirausahaan (Afiah, 2009).

Industri pengolahan adalah suatu kegiatan ekonomi yang melakukan kegiatan mengubah suatu bahan dasar secara mekanis, kimia, atau dengan tangan, sehingga menjadi barang jadi/setengah jadi; dan atau dari barang yang kurang nilainya menjadi barang yang lebih tinggi nilainya, dan sifatnya lebih dekat kepada pemakai akhir. Industri pengolahan pangan memanfaatkan hasil pertanian sebagai bahan baku produknya, baik bahan baku impor maupun hasil pertanian lokal.

Di lima daerah tingkat II yang ada di Provinsi DIY banyak sekali industri pengolahan pangan, mulai dari yang skala industri rumah tangga, industri kecil dan industri menengah, bahkan ada yang masuk ke golongan industri besar. Dari 253 sentra industri kecil dan menengah di Provinsi DIY, 81 diantaranya merupakan sentra industri pengolahan pangan (Tabel 1).

Industri mikro pengolahan pangan, yang jumlahnya 3.766 unit usaha, menggunakan bahan baku hasil pertanian yang beragam, sebagian menggunakan hasil pertanian lokal, sebagian menggunakan hasil pertanian yang diimpor dari negara lain sebagai bahan baku produknya. Tentu saja industri ini akan menghadapi permasalahan terkait dengan bahan baku yang pada umumnya bersifat musiman, padahal produk yang dihasilkan diharapkan bisa stabil sepanjang tahun, baik dalam jumlah produksi maupun dalam harga jual produknya. Hal ini penting bagi kelangsungan hidup industri tersebut, karena akan mempengaruhi popularitas produk pada konsumen yang pada akhirnya akan mempengaruhi laju permintaan produk.

Banyak industri rumah tangga dan industri kecil yang sudah sangat lama (puluhan tahun) beroperasi, namun sampai saat ini masih juga termasuk dalam skala industri rumah tangga atau kecil. Kondisi demikian bisa dikatakan bahwa industri tersebut tidak berkembang, hal ini sangat menarik untuk dikaji penyebabnya. Juga sangat menarik untuk diteliti tentang karakter wirausaha pelaku usaha dan faktor-faktor yang mempengaruhinya, karena akan mempengaruhi perkembangan usahanya.

\section{METODE PENELITIAN}

Metode dasar yang digunakan dalam penelitian ini adalah descriptive method (metode deskriptif), yaitu upaya menggambarkan hubungan antar fenomena, menguji hipotesis, dan membuat implikasi terkait dengan karakter kewirausahaan (Nasir, 1989); dalam arti lain pengukuran yang cermat terhadap fenomena karakter kewirausahaan industri pengolahan pangan (Singarimbun dan Effendi, 1989). Penelitian ini bertujuan untuk mengetahui karakter kewirausahaan pelaku usaha dan pengaruhnya

TABEL I. POTENSI INDUSTRI KECIL-MENENGAH PROVINSI DIY

\begin{tabular}{lllllll}
\hline No & Cabang Industri & Sentra & Unit Usaha (unit) & TenagaKeria (orang) & Nilai Investasi (Rp.000) & Nilai Produksi (unit) \\
\hline 1. & Pangan & 81 & 3766 & 10585 & 9801892 & 155894022 \\
2. & Sandang\& Kulit & 25 & 1513 & 4304 & 7045197 & 5113615 \\
3. & Kimia \& bhn bangunan & 59 & 5540 & 16888 & 21982009 & 169056600 \\
4. & Logam\&Elektronik & 18 & 420 & 1749 & 7273289 & 1936346 \\
5. & Kerajinan & 70 & 3619 & 13395 & 11521256 & 3369228 \\
& JUMLAH & 253 & 14860 & 46921 & 57623643 & 335369811 \\
\hline
\end{tabular}


TABEL 2. NILAI RATA-RATA INDIKATOR WIRAUSAHA PELAKU USAHA (SKALA LIKERT), FAKTOR

\begin{tabular}{clcclc}
\hline No & Indikator Wirausaha & Nilai & No & Lingkungan Internal & Nilai \\
\hline 1. & Keterampilan & 2,33 & 1. & Tingkat pendidikan (tahun) & 7 \\
2. & Kreativitas & 1,20 & 2. & Pengalaman usaha (tahun) & 19,13 \\
3. & Kepercayaan & 2,73 & 3. & Sifat ekstroversi pelaku usaha (Likert) & 2,79 \\
\cline { 3 - 5 } 4. & Penerimaan risika & 1,60 & No & Lingkungan Eksternal & Nilai \\
5. & Orientasi pasar & 2,65 & 1. & Pasar input & 3,97 \\
6. & Kebutuhan berprestasi & 1,81 & 2. & Pasar output & 3,71 \\
7. & Kemandirian & 2,05 & 3. & Ketersedian sarana transportasi & 3,54 \\
& & & 4. & Perkembangan teknologi informasi & 3,30 \\
& & 5. & Dukungan pemerintah & 2,26 \\
& & 6. & Dukungan masyarakat & 1,5 \\
& & 7. & Dukungan keluarga & 3,77 \\
\hline
\end{tabular}

terhadap efisiensi produksi, sehingga data yang didapat akan diestimasi dengan menggunakan fungsi produksi fixed proportion input.

Penelitian dilaksanakan di lima wilayah Dati II Provinsi DIY, dari masing-masing kabupaten ditentukan produk yang paling banyak produsennya/unit usahanya. Selanjutnya untuk memperoleh sampel ditentukan secara quota simple random sampling. Jumlah sampel ditentukan sebanyak 60 sampel untuk tiap jenis usaha, sehingga untuk seluruh kabupaten daerah tingkat II di provinsi DIY didapatkan sebanyak 300 sampel.

Data primer dikumpulkan dari pelaku usaha melalui pengamatan langsung di lapangan dan wawancara menggunakan kuesioner yang telah dipersiapkan. Informasi umum dan kebijakan dikumpulkan melalui wawancara dengan informan kunci, mulai dari tingkat provinsi sampai ke tingkat kabupaten. Sementara data sekunder diperoleh dari instansi pemerintah yang berkompeten.

Indikator karakter kewirausahaan dari pelaku usaha meliputi: i) keterampilan, ii) kreativitas, iii) kepercayaan diri, iv) perencanaan usaha, v) orientasi pasar, vi) kebutuhan berprestasi, v) kemandirian. Faktor lingkungan internal meliputi: i) tingkat pendidikan, ii) pengalaman usaha, dan iii) sifat ekstroversi pelaku usaha. Faktor lingkungan eksternal terdiri atas: i) pasar input, ii) pasar output, iii) ketersediaan sarana prasarana transportasi, iv) perkembangan teknologi informasi dan komunikasi, v) dukungan pemerintah, vi) dukungan masyarakat, dan g) dukungan keluarga. Variabel penelitian ini terlebih dahulu didefinisikan berdasarkan cara operasionalnya untuk mempermudah proses pengumpulan data, kemudian di nilai dalam 5 skala Likert.

Data karakter wirausaha dianalisis secara deskripsi menggunakan analisis, selanjutnya dilakukan analisis jalur (path analysis) untuk menjelaskan hubungan kausalitas antara karakter wirausaha dengan efisiensi usaha. Efisiensi usaha dihitung dari perbandingan antara besarnya penerimaan dengan biaya yang dikeluarkan untuk berproduksi, yaitu dengan menggunakan $\mathrm{R} / \mathrm{C}$ rasio (revenue cost ratio). Perhitungan R/C dibedakan, antara R/ $\mathrm{C}$ yang menggunakan biaya yang secara riil dikeluarkan pengusaha; dan $\mathrm{R} / \mathrm{C}$ yang menghitung semua biaya, baik biaya yang riil dikeluarkan maupun biaya yang tidak riil dikeluarkan (Soekartawi, 1995).

\section{HASIL DAN PEMBAHASAN}

Berdasarkan nilai indikator yang diperoleh (Tabel 2), karakter wirausaha dari pelaku usaha bisa dikatakan kurang kuat dilihat dari rendahnya nilai rata-rata sebagian besar indikator, seperti keterampilan $(2,23)$, kreativitas $(1,20)$, penerimaan risiko $(1,6)$, kebutuhan berprestasi $(1,81)$, dan kemandirian $(2,05)$. Nilai indikator yang cukup tinggi ada pada kepercayaan diri $(2,73)$, orientasi pasar $(2,65)$ dan sifat ekstroversi pelaku usaha $(2,79)$.

Faktor lingkungan internal adalah faktor-faktor yang berasal dari dalam diri pelaku usaha pangan olahan, seperti tingkat pendidikan, umur, lama berusaha, jumlah tanggungan keluarga dan ditambah karakter wirausaha yang dipandang dekat keterkaitannya. Hasil penelitian faktor lingkungan internal yang utama bisa dicermati pada Tabel 3. 
TABEL 3. FAKTOR INTERNAL PELAKU USAHA PANGAN OLAHAN

\begin{tabular}{|c|c|c|c|}
\hline No. & $\begin{array}{l}\text { Indikator } \\
\text { Usia }\end{array}$ & \multicolumn{2}{|c|}{$\begin{array}{l}\text { Hasil Pengukuran } \\
\text { (Tahun) }\end{array}$} \\
\hline \multirow[t]{2}{*}{1.} & Rata-rata & \multirow{2}{*}{\multicolumn{2}{|c|}{$\begin{array}{c}47,6 \\
29-70\end{array}$}} \\
\hline & Kisaran & & \\
\hline \multirow[t]{5}{*}{2} & Tingkat pendidikan (distribusi) & (orang) & $(\%)$ \\
\hline & Lulus SD & 221 & 73,7 \\
\hline & Lulus SMP & 46 & 13,3 \\
\hline & Lulus SMA & 30 & 10 \\
\hline & Lulus perguruan tinggi & 3 & 1 \\
\hline \multirow[t]{3}{*}{3.} & Jumlah tanggungan keluarga para pelaku usaha & \multicolumn{2}{|c|}{ (Orang) } \\
\hline & Rata-rata & \multicolumn{2}{|c|}{4} \\
\hline & Kisaran & & \\
\hline \multirow[t]{3}{*}{4.} & Lama berusaha & \multicolumn{2}{|c|}{ (Tahun) } \\
\hline & Rata-rata & \multicolumn{2}{|c|}{19,13} \\
\hline & Kisaran & \multicolumn{2}{|c|}{$3-31$} \\
\hline \multirow[t]{4}{*}{5.} & Jarak lokasi usaha (terdekat - terjauh) dari: & \multirow{2}{*}{\multicolumn{2}{|c|}{$\begin{array}{c}(\mathrm{Km}) \\
1-20\end{array}$}} \\
\hline & a. ibukota kabupaten & & \\
\hline & b. ibukota provinsi & \multicolumn{2}{|c|}{$0,5-50$} \\
\hline & c. lembaga pendidikan tinggi & \multicolumn{2}{|c|}{$1-30$} \\
\hline
\end{tabular}

TABEL 4. PERSEPSI PELAKU USAHA RUMAH TANGGA PANGAN OLAHAN ATAS FAKTOR ERSTERNAL

\begin{tabular}{|c|c|c|c|c|c|c|c|c|c|c|c|c|}
\hline \multirow{3}{*}{ Indikator } & \multicolumn{10}{|c|}{ Distribusi responden berdasarkan skor persepsi (orang) } & \multirow{2}{*}{\multicolumn{2}{|c|}{$\begin{array}{l}\text { Skor } \\
\text { (skala Likert) }\end{array}$}} \\
\hline & \multicolumn{2}{|c|}{ Skor 1} & \multicolumn{2}{|c|}{ Skor 2} & \multicolumn{2}{|c|}{ Skor 3} & \multicolumn{2}{|c|}{ Skor 4} & \multicolumn{2}{|c|}{ Skor 5} & & \\
\hline & $\Sigma$ & $\%$ & $\Sigma$ & $\%$ & $\Sigma$ & $\%$ & $\Sigma$ & $\%$ & $\Sigma$ & $\%$ & Rerata & Maks \\
\hline $\begin{array}{l}\text { Ketersediaan } \\
\text { Input }\end{array}$ & 0 & 0 & 7 & 2,33 & 119 & 39,67 & 60 & 20 & 114 & 38 & 3,97 & 3 \\
\hline Pasar output & 0 & 0 & 0 & 0 & 189 & 63 & 8 & 2,67 & 103 & 34,33 & 3,71 & 3 \\
\hline $\begin{array}{l}\text { Sarana-prasarana } \\
\text { transportasi }\end{array}$ & 0 & 0 & 59 & 19,67 & 83 & 27,67 & 94 & 31,33 & 64 & 21,33 & 3,54 & 4 \\
\hline $\begin{array}{l}\text { Kemajuan teknologi } \\
\text { informasi }\end{array}$ & 0 & 0 & 85 & 28,33 & 93 & 31 & 70 & 23,33 & 52 & 17,33 & 3,30 & 3 \\
\hline Dukungan Pemerintah & 131 & 43,67 & 95 & 31,67 & 0 & 0 & 14 & 4,67 & 60 & 20 & 2,26 & 1 \\
\hline Dukungan Masyarakat & 210 & 70 & 30 & 10 & 60 & 20 & 0 & 0 & 0 & 0 & 1,5 & 1 \\
\hline $\begin{array}{l}\text { Dukungan } \\
\text { Keluarga }\end{array}$ & 0 & 0 & 60 & 20 & 9 & 3 & 171 & 57 & 60 & 20 & 3,77 & 4 \\
\hline
\end{tabular}

Pada Tabel 3 bisa dilihat bahwa usia rata-rata pelaku usaha rumah tangga pangan olahan adalah 47,6 tahun, walau masih termasuk kelompok usia produktif tapi sudah cukup tua hampir mencapai batas atas usia produktif. Bahkan pelaku usaha yang tertua termasuk kelompok usia yang sudah tidak produktif, yaitu 70 tahun. Memang ada regenerasi dilihat dari usia termuda pelaku usahanya adalah 29 tahun dan dari data yang ada, pelaku usaha termuda ini sudah mulai berusaha sejak usia 19 tahun. Sementara itu pelaku usaha tertua (70 
tahun) ternyata baru mulai berusaha pada usia 50 tahun karena pengalaman berusaha baru 20 tahun.

Dilihat perkembangan usahanya, sampai lama usaha rata-rata hampir 20 tahun skala usahanya masih tetap mikro, jadi termasuk tidak berkembang. Hal ini bisa disebabkan karena usaha pangan olahan tidak dikelola secara maksimal. Pada umumnya bagi pelaku usaha mikro pangan olahan asalkan setiap hari masih bisa berproduksi dengan jumlah tetap sudah cukup, sehingga upaya pengembangan jangkauan pemasaran juga tidak dilakukan maksimal, pelaku usaha cenderung hanya melayani konsumen yang sudah biasa membeli produknya. Pelaku usaha dengan lokasi usaha jauh dari pusat pemerintahan kota, kabupaten atau provinsi, lebih memilih memasarkan produknya ke pengumpul.

Faktor lingkungan eksternal adalah faktor di luar kapasitas pribadi pelaku usaha yang diperkirakan berpengaruh terhadap kewirausahaan dan pertumbuhan karakter wirausahanya. Faktor-faktor yang dimaksud meliputi dukungan keluarga, dukungan pemerintah, dukungan masyarakat, pasar input, pasar output, perkembangan teknologi informasi dan sarana-prasarana transportasi (Tabel 4).

Berdasarkan rekapitulasi yang disajikan pada Tabel 4 tanggapan responden terhadap kapasitas faktor eksternal cukup beragam. Kebutuhan input produksi selalu terpenuhi, terbukti dengan proporsi responden yang mendapat skor persepsi yang bernilai $3(39,67 \%)$ dan 5 (38\%), hampir sama. Bagi mereka pada kondisi tertentu, seperti tidak pada musimnya, harga bahan baku menjadi mahal tidak masalah asal barangnya masih bisa didapat. Bahkan sebagian dari mereka berpendapat bahwa input selalu tersedia dengan harga yang masih wajar.

Ketersediaan input diukur berdasarkan perkembangan ketersediaan dan harganya di pasar input pada 2 tahun terakhir, mengingat input utama berupa hasil pertanian yang harganya sering berubah sesuai ketersediaannya.

Sementara itu tanggapan responden terhadap kondisi pasar output didominasi pernyataan bahwa permintaan terhadap produk olahan dan harga fluktuatif, namun masih selalu mendapat keuntungan (63\%). Diikuti dengan tanggapan bahwa pada waktu tertentu permintaan akan produk maupun harganya meningkat $(34,33 \%)$. Hal inilah yang kemungkinan besar menjadi alasan mereka tetap menekuni usaha produksi pangan olahan. Tidak ada masalah dalam ketersediaan bahan bakunya, selalu ada permintaan akan produknya dan masih selalu mendapatkan keuntungan. Pengukuran kondisi pasar output berdasarkan atas kondisi permintaan produk dan kondisi harga jual yang bisa dicapai oleh perusahaan.

Persepsi responden terhadap kondisi sarana prasarana transportasi cukup beragam sesuai dengan wilayah tempat usahanya. Tanggapan terbanyak mengatakan bahwa kondisi jalan baik dengan ketersediaan angkutan umum juga baik dan bertambah banyak (31,33\%). Namun demikian, ada juga yang mengatakan bahwa kondisi jalan yang biasa dilalui dalam kegiatan berusaha jelek dengan angkutan umum yang tersedia baik, walaupun jarang/ tidak banyak (27,67\%). Sebagian lagi memberikan penilaian bahwa kondisi jalan terus diperbaiki dengan angkutan umum yang semakin baik dan jumlahnya semakin banyak (21,33\%). Adapun wilayah yang kondisi sarana prasarananya cukup menurut responden juga ada, yaitu yang kondisi jalan sudah ada perbaikan dan angkutan umum baik walau jumlahnya belum banyak $(19,67 \%)$. Berdasarkan uraian di atas dapat dikatakan bahwa tidak ada masalah yang menyebabkan kendala dalam berusaha dari segi sarana prasarana transportasi. Pengukuran persepsi perkembangan sarana dan prasarana transportasi, diindikasikan dengan pendapat pelaku usaha berhubungan dengan sarana prasarana transportasi untuk mencapai lokasi usahanya. Aspek prasarana umum yang dapat mendorong dan mengembangkan pertumbuhan usaha rumah tangga (mikro) dan kecil ini bahkan diatur dalam UU No 20 tahun 2008 tentang UMKM, pasal 7 ayat (1) huruf b. (Leonardus, 2009).

Teknologi informasi merupakan kebutuhan penting dalam dunia usaha, tidak terkecuali dalam usaha mikro pangan olahan. Berdasarkan Tabel 4 kondisi teknologi informasi menurut persepsi responden, adalah cukup kondusif ditandai dengan pendapat terbanyak (31\%) menyatakan bahwa ketersediaan media komunikasi dan informasi yang semakin banyak macamnya dan mudah diakses. Pengukuran persepsi responden terhadap perkembangan teknologi informasi diindikasikan dengan penjelasan pelaku usaha terhadap item yang ditanyakan dalam perkembangan 2 tahun terakhir meliputi: i) media alat komunikasi, ii) jumlah media alat komunikasi, iii) akses terhadap alat komunikasi, iv) keterjangkauan harga alat komunikasi, dan v) kualitas alat komunikasi.

Untuk dukungan pemerintah, secara rata-rata responden memberikan persepsi yang cukup rendah, artinya dukungan pemerintah menurut sebagian besar responden tidak ada dukungan sama sekali terhadap usaha mereka. Hal itu dibuktikan dengan sebesar 43,67 persen responden menyatakan tidak ada dukungan 
TABEL 5. KOEFISIEN KORELASI FAKTOR YANG BERPENGARUH TERHADAP KARAKTER WIRAUSAHA

\begin{tabular}{|c|c|c|c|c|c|}
\hline \multirow{2}{*}{$\begin{array}{l}\text { Karakter } \\
\text { Wirausaha }\end{array}$} & \multicolumn{5}{|c|}{ Koefisien Korelasi Antar Faktor } \\
\hline & MB & OK & Pim & $\mathrm{JU}$ & MP \\
\hline $\mathrm{FE}$ & 0,711 & 0,322 & 0,297 & 0,591 & 0,224 \\
\hline $\mathrm{Fl}$ & $-0,294$ & 0,058 & 0,251 & 0,233 & 0,086 \\
\hline MB & & 0,544 & 0,439 & 0,325 & 0,491 \\
\hline OK & 0,544 & & 0,803 & 0,521 & 0,502 \\
\hline Pim & 0,439 & 0,803 & & 0,718 & 0,716 \\
\hline JU & 0,325 & 0,521 & 0,718 & & 0,440 \\
\hline MP & 0,491 & 0,502 & 0,716 & 0,440 & \\
\hline
\end{tabular}

Keterangan:

FE: Faktor Eksternal

FI : Faktor Internal

MB: Motivasi Berprestasi
OK: Orientasi Ke depan

Pim: jiwa Kepemimpinan

JU: kepemilikan Jaringan Usaha

MP: kemampuanMenghadapi Perubahan sesuatupun dari pemerintah terhadap usahanya dan 31,67 persen menyatakan pemerintah pernah memberikan penyuluhan terkait usaha mereka. Namun demikian terdapat 20 persen responden yang menyatakan bahwa dukungan pemerintah tinggi, karena selain penyuluhan dan bimbingan teknis, pemerintah juga memberikan pinjaman lunak. Persepsi responden terhadap dukungan pemerintah diukur berdasarkan keterangan responden atas keterlibatan pemerintah yang dirasakan selama menjalankan usahanya dalam kurun waktu 2 tahun terakhir.

Mengenai persepsi responden terhadap dukungan masyarakat, sebagian besar responden (70\%) menyatakan bahwa pada umumnya masyarakat sekitar tidak mau tahu apa yg mereka kerjakan atau hanya memperoleh sedikit kemudahan mendapatkan tenaga kerja tidak tetap pada saat dibutuhkan. Sebagian kecil responden (10\%) menyatakan selain sedikit kemudahan mendapatkan tenaga kerja tidak tetap, juga cukup mudah mendapatkan pinjaman dalam kondisi terpaksa, dan yang 20 persen menyatakan bahwa selain dua pendapat di atas juga adanya rasa ikatan kekerabatan. Pengukuran persepsi responden terhadap dukungan masyarakat diindikasikan berdasarkan keterangan responden atas perlakuan yang diterima/dirasakan selama menjalankan usahanya dalam kurun waktu 2 tahun terakhir dengan kriteria: i) adanya rasa ikatan kekerabatan antar pelaku usaha, ii) mudah mendapatkan pinjaman dalam kondisi terpaksa, iii) kemudahan mendapatkan tambahan tenaga kerja paruh waktu pada saat diperlukan, iv) adanya rasa kebersamaan dalam kelompok usaha, dan v) adanya keterbukaan untuk saling memberikan informasi dan tukar pikiran.

Secara umum responden menilai dukungan keluarga tinggi. Hal ini ditunjukkan dari: 57 persen responden memperoleh dukungan keluarga dalam bentuk sumbangan pemikiran dan juga tenaga sampai produk siap dipasarkan; 20 persen responden menyatakan keluarga mendukung mulai dari pemikiran, tenaga sampai produk siap dipasarkan serta biaya produksi; 20 persen lagi mendukung dalam bentuk pemikiran saja; dan 3 persen sisanya menyatakan bahwa keluarga mendukung dalam bentuk pemikiran dan tenaga saja. Persepsi responden terhadap dukungan keluarga diukur berdasarkan penjelasan pelaku usaha mengenai dukungan keluarga yang diperolehnya.

Faktor-Faktor yang Mempengaruhi Karakter Wirausaha

Karakter seseorang tidak sepenuhnya merupakan sifat manusia sejak dilahirkan, tapi bisa terbentuk karena pengaruh berbagai faktor yang terjadi selama hidupnya. Berpijak dari arti karakter dalam kamus Purwadarminta, yaitu sifat-sifat kejiwaan yang membedakan seseorang dari yang lain, Suryana dan Bayu (2011) berpendapat bahwa karakter dibangun melalui proses yang akhirnya dapat membentuk jiwa seseorang yang berbeda dari yang lain. Dalam penelitian ini dilakukan analisis terhadap faktorfaktor yang mempengaruhi karakter wirausaha dari responden berdasarkan sifat-sifat pendukung karakter wirausaha dengan hasil seperti tercantum di Tabel 5 .

Pada Tabel 5 dicantumkan estimasi koefisien korelasi 
antar faktor-faktor dalam karakter wirausaha hasil analisis jalur. Koefisien korelasi mempunyai rentang nilai Od^\%koefisien\%d” 1. Pengaruh yang dianggap kuat apabila koefisien korelasinya $>0,50$.

Berdasarkan Tabel 4 dapat dilihat keeratan hubungan antar faktor, yang bisa dijadikan pendugaan pengaruhnya terhadap karakter wirausaha dari responden. Untuk masing-masing karakter wirausaha ternyata mempunyai hubungan erat dengan lebih dari satu faktor lain (koefisien korelasi $>0,500$ ). Karakter motivasi berprestasi dari responden mendapat pengaruh paling kuat dari faktor eksternal $(0,711)$ dan berikutnya adalah dari faktor karakter orientasi ke depan dari responden $(0,544)$. Artinya motivasi berprestasi dari responden akan meningkat apabila faktor eksternal juga meningkat, didukung dengan faktor orientasi ke depan yang dimilikinya. Dengan demikian usaha akan berkembang sesuai karakter yang dimilikinya dan besar/kuatnya pengaruh faktor lain yang mempengaruhinya.

Karakter orientasi ke depan dari responden paling kuat dipengaruhi oleh karakter jiwa kepemimpinan dari individu $(0,803)$; kepemilikan jaringan usaha $(0,521)$; dan kemampuan menghadapi perubahan $(0,502)$ yang dimiliki oleh responden. Artinya jiwa kepemimpinan seseorang menyebabkan seorang wirausahawan berorientasi ke depan demi keberlangsungan pertumbuhan usahanya, kepemilikan jaringan usaha, dan kemampuan dalam menghadapi perubahan di dunia usaha yang dimiliki secara individual.

Karakter jiwa kepemimpinan responden saling berpengaruh paling kuat dengan faktor karakter orientasi ke depan, juga saling berpengaruh kuat dengan faktor karakter kepemilikan jaringan usaha dan karakter kemampuan menghadapi perubahan. Hal ini berarti jiwa kepemimpinan seorang wirausahawan akan semakin muncul/kuat bila karakter orientasi ke depan yang dimilikinya semakin kuat dan didukung oleh kepemilikannya atas jaringan usaha serta kemampuannya dalam menghadapi perubahan.

Karakter kepemilikan jaringan usaha dari responden berkorelasi terkuat dengan faktor karakter jiwa kepemimpinan yang dimiliki oleh individu, diperkuat oleh korelasinya dengan faktor eksternal dan juga korelasi kuat dengan faktor orientasi ke depan yang dimilikinya. Ini berarti kemampuan seorang wirausahawan menciptakan kepemilikan jaringan usaha yang utama sangat dipengaruhi faktor jiwa kepemimpinan yang dimilikinya didukung faktor eksternal yang kondusif dan karakter orientasi ke depan yang dimilikinya, yang akan menentukan perkembangan usahanya.

Karakter kemampuan menghadapi perubahan yang dimiliki respoden paling kuat dipengaruhi oleh faktor karakter jiwa kepemimpinan yang ditunjukkan dengan koefisien korelasinya yang paling tinggi, diikuti oleh karakter orientasi ke depan yang dimilikinya. Berarti faktor karakter jiwa kepemimpinan paling berpengaruh terhadap segala keputusan yang diambil responden dalam menghadapi perubahan lingkungan usahanya, hal ini juga didukung terutama oleh faktor orientasi ke depan yang dimilikinya, sedangkan faktor-faktor lain yang berpengaruh signifikan walau tidak terlalu kuat adalah faktor motivasi berprestasi dan kepemilikan jaringan usaha oleh responden.

Karakter wirausaha yang berperan paling penting karena pengaruhnya terhadap karakter yang lain adalah karakter jiwa kepemimpinan. Karakter jiwa kepemimpinan memiliki pengaruh kuat terhadap karakter orientasi ke depan, karakter kepemilikan jaringan usaha dan karakter tanggap dan kreatif menghadapi perubahan. Berikutnya yang memiliki pengaruh kuat adalah karakter orientasi ke depan, yang mempengaruhi karakter motivasi berprestasi, karakter kepemilikan jaringan usaha, karakter tanggap dan kreatif menghadapi perubahan dengan koefisien korelasi lebih rendah dibanding karakter jiwa kepemimpinan.

Karakter jiwa kepemimpinan ada pada level cukup kuat, sehingga apabila ditingkatkan akan meningkatkan juga kapasitas karakter wirausaha yang dipengaruhinya. Demikian juga untuk karakter orientasi ke depan yang juga ada pada level cukup kuat.

\section{KESIMPULAN}

Karakter motivasi berprestasi cukup rendah, karakter orientasi ke depan rendah, karakter jiwa kepemimpinan rendah, karakter kepemilikan jaringan usaha rendah, karakter tanggap dan kreatif menghadapi perubahan masih rendah. Faktor-faktor yang mempengaruhi karakter wirausaha dari responden adalah: a) karakter motivasi berprestasi paling kuat dipengaruhi oleh faktor eksternal, b) karakter orientasi ke depan paling kuat dipengaruhi oleh jiwa kepemimpinan c) karakter jiwa kepemimpinan, paling kuat dipengaruhi oleh orientasi ke depan d) karakter kepemilikan jaringan usaha paling kuat dipengaruhi oleh jiwa kepemimpinan, e) karakter tanggap dan kreatif menghadapi perubahan paling kuat dipengaruhi oleh jiwa kepemimpinan. 


\section{DAFTAR PUSTAKA}

Afiah, N.N. 2009. Peran Kewirausahaan dalam

Memperkuat UKM Indonesia Menghadapi Krisis

Finansial Global. Working Paper in Accounting and

Finance, Department of Accounting, Padjadjaran

University

Nasir, M. 1989. Metode penelitian. Jakarta: Ghalia Indonesia.

Kusnendi, 2008. Model-model Persamaan Struktural Satu dan Multi Group sampel dengan LISREL. Bandung: Penerbit Alfabeta.

Leonardus, S. 2014. Kewirausahaan. Teori, Praktik, dan Kasus-kasus. Jakarta: Penerbit Salemba Empat.

Singarimbun, M., dan S. Effendi, 1989, Metode Penelitian Survei. Jakarta: Lembaga Penelitian Pendidikan dan Penerangan Ekonomi Sosial (LP3ES).

Soekartawi. 1995. Teori Ekonomi Produksi dengan Pokok Bahasan Analisis Cobb-Douglas. Jakarta: Raja Grafindo Persada.

Subanar, H. 2009. Manajemen Usaha Kecil. Yogyakarta: BPFE.

Suparyanto. 2012. Kewirausahaan. Konsep dan Realita pada Usaha Kecil. Bandung: Penerbit Alfabeta.

Suryana, Y., dan B. Krisnamurthi, 2011. Kewirausahaan, Pendekatan Wirausahawan Sukses. Jakarta: Prenada Media Group. 